\title{
Decreased Glutathione Peroxidase in Neonatal Erthyrocytes: Lack of Relation to Hydrogen Peroxide Metabolism
}

\author{
Bertil E. Glader ${ }^{[23]}$ and Margel E. Conrad \\ Department of Hematology, Walter Reed Army Institute of Research, Walter Reed Army Medical Center, Washington, D.C., USA
}

\begin{abstract}
Extract
Glutathione (GSH) oxidation and hexose monophosphate (HMP) shunt activity were compared in cord and adult erythrocytes (RBC) stressed with hydrogen peroxide $\left(\mathrm{H}_{2} \mathrm{O}_{2}\right)$. In the absence of glucose, $\mathrm{GSH}$ (micromoles per milliliter $\mathrm{RBC}$ ) in cord erythrocytes decreased from $2.52 \pm 0.20(0 \mathrm{hr})$ to $1.37 \pm 0.30(2 \mathrm{hr})$ to 0.92 $\pm 0.22(4 \mathrm{hr})$. Adult erythrocytes treated similarly manifested a GSH change from $2.23 \pm 0.17(0 \mathrm{hr})$ to $1.06 \pm 0.24(2 \mathrm{hr})$ to $0.59 \pm 0.35(4 \mathrm{hr})$. The activity of HMP shunt (micromoles $\mathrm{CO}_{2} / \mathrm{ml} \mathrm{RBG/hr}$ ) in cord erythrocytes increased from a control rate of $0.081 \pm 0.015$ to $0.203 \pm 0.52$ when stressed with hydrogen peroxide. Erythrocytes from adults had a resting rate of $0.062 \pm 0.014$ that increased to $0.212 \pm 0.045$ when incubated with $\mathrm{H}_{2} \mathrm{O}_{2}$. Sodium ascorbate also was used as a peroxide-generating agent, and resulted in qualitatively similar responses as $\mathrm{H}_{2} \mathrm{O}_{2}$ in both GSH oxidation and HMP shunt activity of neonatal and adult erythrocytes.
\end{abstract}

\section{Speculation}

The partial deficiency of GSH-peroxidase in erythrocytes from neonates probably is not functionally significant in the intact cell. More functional studies are necessary to ascertain which of the many differences between erythrocytes from neonates and adults may be related to the increased oxidant sensitivity of these cells. In addition, these data again point out that there is often a poor correlation between isolated enzyme assays and the manner in which an enzyme functions within the intact cell. In the case of hemolytic anemias associated with enzyme abnormalities, more functional cellular tests of specific enzymes would be useful in attempting to correlate altered enzyme activity with cell function and hemolysis.

\section{Introduction}

Erythrocytes from normal term neonates are considered to be more sensitive to oxidant stresses than are exythrocytes from adults [9]. This sensitivity is manifested by increased methemoglobin formation and Heinz bodies when erythrocytes are stressed with oxidant drugs. It is thought that most oxidant drugs exert an oxidative stress by generating hydrogen peroxide within erythrocytes [6]. RBC's from cord blood are partially deficient in glutathione peroxidase [9] and catalase [11] activity, both of which are required for the detoxification of hydrogen peroxide. Gross [9] suggested that it is possible that decreased levels of glutathione peroxidase may be partially responsible for the 
increased oxidant sensitivity of normal erythrocytes from neonates, whereas Steinberg and Necheles [16] believe that hemolytic anemia due to partial glutathione peroxidase deficiency occurs. The present study determines the relative capacity of exythrocytes from neonates to contend with hydrogen peroxide. Glutathione (GSH) oxidation and the response of the hexose monophosphate (HMP) shunt to a peroxide stimulus is compared in erythrocytes from neonates and adults. We concluded from these studies that the relative deficiency of GSH-peroxidase activity in erythrocytes from neonates is probably not significant functionally. The increased oxidant sensitivity of erythrocytes from neonates must be due to other factors yet to be determined.

\section{Methods}

\section{Preparation of Erythrocytes}

Blood was obtained either from the cord of normal term infants at the time of delivery or from apparently healthy adults. Blood was collected in EDTA, refrigerated, and used within $48 \mathrm{hr}$ of collection. We determined previously that refrigerated blood used within this period of time can be used with no loss of enzymatic activity or HMP shunt responsiveness. In pilot experiments heparin was used as the anticoagulant and showed no difference in results obtained with ethylenediaminetetraacetic acid (EDTA). Erythrocytes were separated from the plasma and buffy coat by centrifugation at $4^{\circ}$. Then erythrocytes were washed four times with a pH 7.4 phosphate-buffered salt solution (PBS) which contained $110 \mathrm{~mm} \mathrm{NaCl}, 4 \mathrm{~mm} \mathrm{KH}_{2} \mathrm{PO}_{4}$, and $20 \mathrm{~mm} \mathrm{Na} \mathrm{NPO}_{4}$. After the final wash, the cells were suspended to a hematocrit of $20 \%$ in PBS. The blood was then processed according to methods described for the specific experiment.

\section{Hydrogen Peroxide Diffusion System}

Suspensions of erythrocytes $(4 \mathrm{ml})$ were placed in a 25-ml Erlenmeyer flask with a center well which contained $0.2 \mathrm{ml} 30 \% \quad \mathrm{H}_{2} \mathrm{O}_{2}$ as described previously by Cohen and Hochstein [4]. Hydrogen peroxide vapors diffuse from the center well into the incubation medium. The amount of $\mathrm{H}_{2} \mathrm{O}_{2}$ reaching the main compartment was determined by trapping of $\mathrm{H}_{2} \mathrm{O}_{2}$ with 2 $\mathrm{N}_{2} \mathrm{SO}_{4}$ at various time intervals, and then titration with $0.01 \mathrm{~N} \mathrm{KMnO}_{4}$. This system delivers $4-5 \mu$ moles $\mathrm{H}_{2} \mathrm{O}_{2} /$ hr over a 4 -hr period. The concentration of peroxide delivered to $4 \mathrm{ml}$ PBS was determined by acidifying with $\mathrm{H}_{2} \mathrm{SO}_{4}$ before titration, and this value is similar to that delivered to $\mathrm{H}_{2} \mathrm{SO}_{4}$. When erythrocytes from adults were present in the PBS, acidification of incubation medium at 1,2 , and $4 \mathrm{hr}$ indicated that $\mathrm{H}_{2} \mathrm{O}_{2}$ concentration in the extracellular medium is 0.5 , 1.0, and $1.8 \mathrm{~mm}$.

\section{Experimental Procedure}

All incubations were performed in an Eberbach water-bath shaker at $37^{\circ}$ and 100 oscillations/min. The suspensions were covered after exposure to room air. The effect of various metabolic alterations on stability of GSH in erythrocytes of infants and adults was determined. Cells were preincubated with or without glucose $(10 \mathrm{~mm})$ for $1 \mathrm{hr}$ before the beginning of an experiment. Neutralized sodium cyanide [17] was used to inhibit catalase and was added 10 min before beginning an experiment to a final concentration of $10 \mathrm{~mm}$. In some experiments $20 \mathrm{~mm}$ neutralized sodium ascorbate [18] was used as a peroxide stress instead of the $\mathrm{H}_{2} \mathrm{O}_{2}$ diffusion flask. Reduced glutathione was measured according to the method of Beutler [3]. Glutathione peroxidase was assayed as described by Paglia and Valentine [14], except that the assay was run at $25^{\circ}$.

\section{Measurement of Hexose Monophosphate Shunt Activity}

( Oxidation of glucose-1-14 $\mathrm{C}$ to ${ }^{14} \mathrm{CO}_{2}$ was used as an indicator of hexose monophosphate (HMP) shunt activity. Glucose-1-14 C [19] was added to erythrocytes in PBS to a final concentration of $10 \mathrm{~mm}$ glucose and a specific activity for glucose of approximately 0.0015 ${ }_{\mu} \mathrm{Ci} / \mu$ mole glucose. The suspensions of erythrocytes were covered with rubber stoppers and allowed to incubate for $4 \mathrm{hr}$ under the same incubation conditions as those described above. Radiolabeled $\mathrm{CO}_{2}$ was liberated by the injection of $\mathrm{Iml}$ of $0.5 \mathrm{~N} \mathrm{H}_{2} \mathrm{SO}_{4}$, and trapped in $0.2 \mathrm{ml}$ hyamine hydroxide [20] contained in a plastic cup suspended from the rubber stopper. The deproteinized cell suspension was allowed to incubate for an additional $30 \mathrm{~min}$. The plastic cups were then placed in liquid scintillation vials containing $10 \mathrm{ml}$ counting fluid with the following composition: toluene (1000 $\mathrm{ml}), 2$,5-diphenyloxazole (4 g), and 1,4-bis[2-(5-phenyloxazolyl)]benzene $(0.1 \mathrm{~g})$. The samples were cooled and counted for $10 \mathrm{~min}$ in a Packard Tri-Carb liquid scintillation spectrometer with a background of less than $20 \mathrm{cpm}$. Nonspecific formation of ${ }^{14} \mathrm{CO}_{2}$ was determined by adding sulfuric acid to the suspension of RBC immediately after introduction of labeled glucose. The radioactivity in this sample was subtracted from all subsequent determinations. 
Table I. Effect of peroxide stress on oxidation of GSH in erythrocytes from cord blood and from adults ${ }^{1}$

\begin{tabular}{|c|c|c|c|c|}
\hline & \multicolumn{4}{|c|}{ GSH, $\mu$ moles $/ \mathrm{ml}$ erythrocytes } \\
\hline & $0 \mathrm{hr}$ & & $2 \mathrm{hr}$ & $4 \mathrm{hr}$ \\
\hline \multicolumn{5}{|l|}{$\begin{array}{l}\text { Hydrogen peroxide dif- } \\
\text { fusion system }\end{array}$} \\
\hline Cord + glucose & $2.44 \underset{(12)}{ \pm 0} 0.28$ & 2.23 & $\begin{array}{l} \pm 0.26 \\
(6)\end{array}$ & $\begin{array}{c}2.18 \pm 0.38 \\
(9)\end{array}$ \\
\hline Adult + glucose & $\begin{array}{c}2.18 \pm 0.23 \\
(14)\end{array}$ & 2.06 & $\begin{array}{l} \pm 0.30 \\
(7)\end{array}$ & $\begin{array}{c}2.13 \pm 0.50 \\
(10)\end{array}$ \\
\hline Cord & $\begin{array}{c}2.52 \underset{(16)}{ \pm 0.20} \\
\text { (16) }\end{array}$ & 1.37 & $\begin{array}{l} \pm 0.30 \\
(16)\end{array}$ & $\begin{array}{c}0.92 \text { 士 } 0.22 \\
(9)\end{array}$ \\
\hline Adult & $\begin{array}{c}2.23 \pm 0.17 \\
(19)\end{array}$ & 1.06 & $\begin{array}{l} \pm 0.24 \\
(19)\end{array}$ & $\begin{array}{c}0.59 \pm 0.35 \\
(9)\end{array}$ \\
\hline $\begin{array}{c}\text { Cord }+ \text { glucose } \\
\text { sodium cyanide }\end{array}$ & $\begin{array}{c}2.23 \text { 土0.17 } \\
\text { (5) }\end{array}$ & 2.14 & $\begin{array}{l} \pm 0.24 \\
(5)\end{array}$ & \\
\hline $\begin{array}{l}\text { Adult }+ \text { glucose }+ \\
\text { sodium cyanide }\end{array}$ & $\begin{array}{c}2.31 \pm 0.14 \\
(5)\end{array}$ & 2.24 & $\begin{array}{l} \pm 0.28 \\
(5)\end{array}$ & \\
\hline $\begin{array}{l}\text { Cord + sodium cya- } \\
\text { nide }\end{array}$ & $\begin{array}{c}2.23 \pm 0.17 \\
\text { (5) }\end{array}$ & 0.56 & $\begin{array}{l} \pm 0.24 \\
(5)\end{array}$ & \\
\hline $\begin{array}{l}\text { Adult + sodium cya- } \\
\text { nide }\end{array}$ & $\begin{array}{c}2.31 \pm 0.14 \\
(5)\end{array}$ & 0.68 & $\begin{array}{l} \pm 0.16 \\
(5)\end{array}$ & \\
\hline \multicolumn{5}{|l|}{ Ascorbate, $20 \mathrm{mM}$} \\
\hline Cord + glucose & $\begin{aligned} 2.59 & \pm 0.31 \\
& (5)\end{aligned}$ & 2.55 & $\begin{array}{l} \pm 0.26 \\
(5)\end{array}$ & $\begin{array}{c}2.47 \pm 0.24 \\
(5)\end{array}$ \\
\hline Adult + glucose & 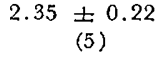 & 2.10 & $\begin{array}{l} \pm 0.19 \\
(5)\end{array}$ & $\begin{array}{c}2.07 \pm 0.50 \\
(4)\end{array}$ \\
\hline Cord & $\begin{array}{c}2.59 \pm 0.31 \\
(5)\end{array}$ & 1.03 & $\begin{array}{l} \pm 0.66 \\
(5)\end{array}$ & $\begin{array}{c}0.13 \pm 0.10 \\
\text { (4) }\end{array}$ \\
\hline Adult & $\begin{array}{c}2.35 \pm 0.22 \\
\stackrel{(5)}{ \pm}\end{array}$ & 0.83 & $\begin{array}{l}\text { 士 } 0.68 \\
(5)\end{array}$ & $\begin{array}{c}0.23 \pm 0.09 \\
\text { (4) }\end{array}$ \\
\hline
\end{tabular}

${ }^{1}$ Results are expressed as means $\pm 1 \mathrm{SD}$. Number of experiments appears in parentheses. GSH : glutathione.

Table II. Effect of peroxide stress on hexosemonophosphate shunt in erythrocytes from neonatal cords and adults ${ }^{1}$

\begin{tabular}{|c|c|c|c|}
\hline & \multicolumn{3}{|c|}{ Hexosemonophosphate shunt activity, $\mu$ moles $\mathrm{CO}_{2} / \mathrm{ml} \mathrm{RBC} / \mathrm{hr}$} \\
\hline & Resting & Ascorbate, $20 \mathrm{msx}$ & $\mathrm{H}_{2} \mathrm{O}_{2}$ \\
\hline Cord & $0.081 \underset{(12)}{ \pm} 0.015$ & $0.630 \underset{(6)}{ \pm} 0.190$ & $0.203 \underset{(10)}{ \pm 0} 0.052$ \\
\hline Adult & $\begin{array}{c}0.062 \pm 0.014 \\
(13)\end{array}$ & $0.547 \underset{(6)}{ \pm 0.132}$ & $\begin{array}{c}0.212 \pm 0.045 \\
(10)\end{array}$ \\
\hline
\end{tabular}

${ }^{1}$ Results are expressed as means $\pm 1 \mathrm{SD}$. Number of experiments appears in parentheses.

\section{Results}

The activity of glutathione peroxidase in newborn red blood cells $(6.6 \pm 1.6 \mathrm{EU} / \mathrm{g} \mathrm{Hb})$ was significantly less than the activity found in erythrocytes from adults $(11.2 \pm 2.5 \mathrm{EU} / \mathrm{g} \mathrm{Hb})$ as described previously [9]

Washed cord and adult red blood cell suspensions were incubated with or without $10 \mathrm{~mm}$ glucose for $4 \mathrm{hr}$ in the hydrogen peroxide diffusion system. During this incubation there were no changes in hematocrit and no evidence of hemolysis. Glucose protected GSH in both preparations (Table I). Without glucose, however, the cell suspensions were not able to maintain GSH in the presence of $\mathrm{H}_{2} \mathrm{O}_{2}$. Of particular interest was the observation that after 2 or $4 \mathrm{hr}$ the amount of GSH oxidized in glucose-deprived cells was similar in cells of adults and infants. If GSH-peroxidase were rate limiting in this system, erythrocytes deficient in the enzyme would theoretically maintain GSH in the presence of a peroxide stress. When catalase was inhibited with $10 \mathrm{~mm} \mathrm{NaCN}$, GSH was stable in the presence of $\mathrm{H}_{2} \mathrm{O}_{2}$ as long as glucose was present in the incubation medium. The GSH content of catalase-inhibited erythrocytes incubated without glucose decreased more than in $\mathrm{H}_{2} \mathrm{O}_{2}$ stressed catalase-intact cells incubated without glucose. This observation demonstrates the magnitude of the peroxide stress and indicates that catalase also was utilized to detoxify $\mathrm{H}_{2} \mathrm{O}_{2}$ in the diffusion system. The use of $20 \mathrm{~mm}$ sodium ascorbate produced qualitatively similar results to the $\mathrm{H}_{2} \mathrm{O}_{2}$ diffusion system. In all of the experiments described above, there was no difference in GSH oxidation between cord and adult erythrocytes.

The resting level of hexosemonophosphate shunt activity of infant erythrocytes was slightly greater than in cells from adults (Table II). Previous studies [13] with premature infants also indicated a more active resting HMP shunt in cord erythrocytes than in erythrocytes from adults. The effect of a peroxide stress on the HMP shunt is also presented in Table II. Ascorbate was used to generate $\mathrm{H}_{2} \mathrm{O}_{2}$ intracellularly and thereby accelerate the HMP shunt. The marked increase in ${ }^{14} \mathrm{CO}_{2}$ production over resting levels was of the same magnitude in red cells from both adults and neonates. The oxidation of glucose- $1{ }^{14} \mathrm{C}$ in erythrocytes suspended in hydrogen peroxide diffusion flasks also was stimulated, although the response was less than that with ascorbate. Again, there was no difference in the amount of extra ${ }^{14} \mathrm{CO}_{2}$ produced in stimulated erythrocytes from adults and from neonates.

\section{Discussion}

In the erythrocyte, glutathione metabolism and hydrogen peroxide degradation are integrally involved in regulating the HMP shunt pathway [10] (Fig. 1). Hydrogen peroxide generated by oxidant drugs or endogenous oxidizing agents is detoxified mainly by GSH in a reaction thought to be mediated by GSH-peroxidase [5]. Catalase also participates in $\mathrm{H}_{2} \mathrm{O}_{2}$ detoxification, but its role is considered to be less important quantitatively as long as GSH is intact [1]. Deficiencies of GSH-peroxidase are reported to be responsible for the increased oxidant sensitivity of erythrocytes from neonates [9] and hemolytic anemia in adults [7].

Our data indicate that the decreased activity of 
GSH-peroxidase in erythrocytes of neonates is probably not of major functional significance. Erythrocytes of infants were stressed with peroxide under conditions where GSH could not be regenerated adequately because of lack of glucose. The amount of GSH oxidized over a 2- to 4-hr period was similar for cord and adult erythrocytes. This result initiated experiments in which GSH was maintained at a constant level and the rate of HMP activity was studied in the presence of a peroxide stress. We compared the peroxide stress of ascorbate and the $\mathrm{H}_{2} \mathrm{O}_{2}$ diffusion system, inasmuch as ascorbate may not be a specific test of the functional integrity of the peroxidase pathway. This agent forms $\mathrm{H}_{2} \mathrm{O}_{2}$ and dehydroascorbate intracellularly, and the dehydroascorbate is capable of direct reaction with $\mathrm{GSH}$, regeneration of ascorbate, and formation of oxidized glutathione (GSSG) [7]. Inasmuch as the GSSG formed during the reduction of dehydroascorbate is capable of stimulating the shunt pathway, the increased glucose- $-1-{ }^{14} \mathrm{C}$ oxidation with ascorbate may not be entirely due to peroxidase-mediated oxidation of GSH. Although ascorbate caused a greater stimulation of the HMP shunt than $\mathrm{H}_{2} \mathrm{O}_{2}$ vapors, there was no difference in either case in the amount of extra ${ }^{14} \mathrm{CO}_{2}$ formed in stimulated red cells from cord blood and adults. Oski [13] demonstrated that the HMP shunts of erythrocytes from neonates and adults were stimulated to the same extent with methylene blue. It was also reported that variations in GSSG-reductase were not rate limiting for the HMP shunt of erythrocytes [15]. If GSHperoxidase were rate limiting, a slower rate of GSH oxidation and a lesser stimulation of the HMP shunt would have been anticipated in cells from cord blood.

There are several possible explanations for this discrepancy between functional cell data and the known decreased GSH-peroxidase activity in erythrocytes of newborns. The relatively decreased activity of this enzyme in erythrocytes from neonates may actually be an excess of what is needed to cope with the oxidant stresses in this study. Several enzymes, one of which is glutathione reductase [15], function intracellularly at a fraction of their maximal activity. Conventional assays for enzyme activity done with ideal substrate concentrations in vitro may have little relation to the way in which an enzyme functions within the cell. The physiologic substrate concentration, spatial localization of enzyme, and other modulating intracellular factors are nonoperative during assays in vitro. In this respect, a functional test of the enzyme within the intact cell (i.e., HMP shunt response to a peroxide stress) actually is more relevant than an isolated assay for enzyme activity.

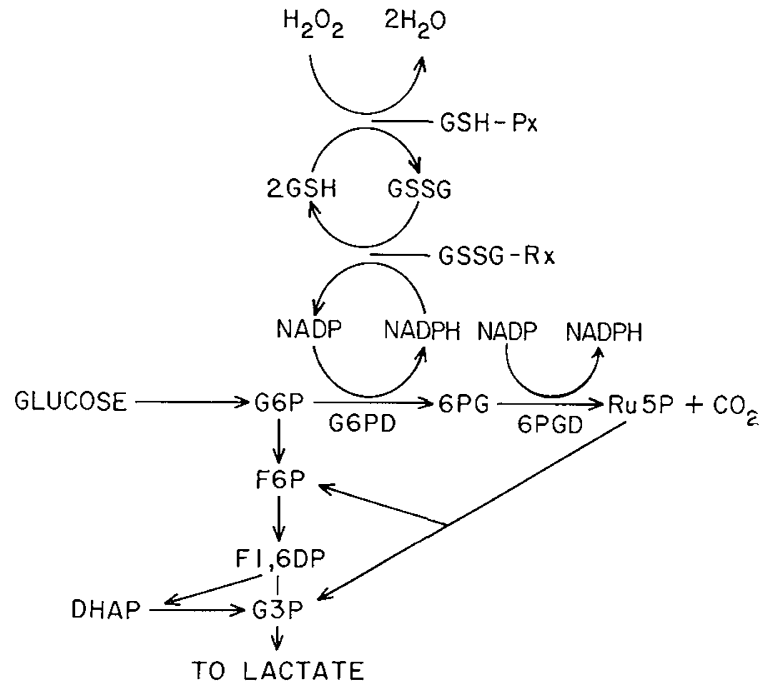

Fig. 1. Abbreviated scheme of glycolysis of exythrocytcs, hexose monophosphate shunt, and related reactions involving degradation of $\mathrm{H}_{2} \mathrm{O}_{2}$ and metabolism of $6 \mathrm{SH}$. Note that alterations in $\mathrm{H}_{2} \mathrm{O}_{2}$ or GSH can influence concentration of GSSG. It is thought [10] that the concentration of GSSG regulates the rate of HMP shunt activity in the intact erythrocyte [10]. GSH-Px: Glutathione peroxidase. GSSG-Rx: Glutathione reductase. G6P: Glucose-6-P. 6PG: 6-Phosphogluconate. Ru5P: Ribulose 5-phosphate. G6PD: glucose-6-phosphate dehydrogenase. 6PGD: 6-Phosphogluconate dehydrogenase. F6P: Fructose-6-P. F1, 6DP: Fructose 1,6-diphosphate. DHAP: Dihydroxyacetone phosphate. G3P: Glyceraldehyde 3-P. GSH: Reduced glutathione. GSSG: Oxidized glutathione.

Another explanation of our data may be related to the kinetic behavior of the enzyme, rather than the amount of available enzyme. Flohe and Brand [8] demonstrated that GSH-peroxidase activity manifested first order kinetics at GSH concentrations between 0.5-16 $\mathrm{mm}$, and that there was no evidence of enzyme saturation with GSH. At physiologic GSH concentrations (2 $\mathrm{mm}$ ), the rate of such a nonsaturable enzymatic process would be limited primarily by GSH rather than by enzyme availability. Although these observations are consistent with out data, further investigations are necessary since Paglia and Valentine [14] observed saturation kinetics, with a Michaelis constant $\left(K_{m}\right)$ for GSH of approximately $10 \mathrm{~mm}$. These latter studies suggest that both GSH and enzyme availability may be important under physiologic conditions.

A significant amount of nonenzymatic GSH oxidation could also explain the similar rate of peroxidestimulated glucose-1-14 $\mathrm{C}$ oxidation in cord red cells and adults. That nonenzymatic oxidation of GSH occurs in vitro is a known phenomenon, and, in fact, is one of the limiting factors in the assay in vitro for GSH-peroxidase [14]. Baehner et al. [2] reported that erythro- 
cyte ghosts were capable of coupling GSH oxidation and $\mathrm{H}_{2} \mathrm{O}_{2}$ degradation. This was a significant observation, inasmuch as exythrocyte ghosts presumably lack GSH-peroxidase [12]. Theoretically, inhibition of GSH-peroxidase in the presence of an oxidant stress could allow one to evaluate the role of nonenzymatic GSH oxidation. Unfortunately, known inhibitors of this enzyme also alter GSH and thereby make it difficult to separate the roles of substrate and enzyme.

Which of these proposed mechanisms is the correct explanation of our data remains to be ascertained. In any event, it is clear that that partial deficiency of GSH-peroxidase in erythrocytes from neonates is probably not related to the increased oxidant sensitivity of these cells. It must be emphasized that the coincidence of an enzyme deficiency and a clinical abnormality are not necessarily related. A case of hemolytic anemia in an adult with $50 \%$ normal GSH-peroxidase activity has been described by Steinberg and Necheles [16]. On the basis of our observations it is difficult to understand why the GSH-peroxidase in the erythrocytes of this individual should be less capable of handling a peroxide load. It would be interesting to know whether there is a more fundamental defect in these cells that results in hemolysis, and coincidentally manifests a decrease in GSH-peroxidase activity in vitro.

\section{Summary}

Our results indicate that a peroxide stress to partially GSH-peroxidase-deficient erythrocytes from neonates stimulates the hexosemonophosphate shunt to the same extent as to enzyme-replete erythrocytes from adults. These observations can be interpreted as follows. (1) There may be an excess of GSH-peroxidase activity in erythrocytes that is capable of coupling GSH oxidation and $\mathrm{H}_{2} \mathrm{O}_{2}$ reduction. The difference in activity between neonatal and adult RBC's may merely indicate a difference of excesses. (2) Oxidation of GSH may occur via an enzyme that is not saturated with substrate, and thereby is more limited by GSH concentration than enzyme availability. (3) There may be a significant amount of nonenzymatic GSH oxidation in the erythrocyte.

Our results do not clearly indicate which of the above mechanisms is applicable intracellularly. Nevertheless, we can conclude that the increased susceptibility of erythrocytes from neonates to oxidant drugs is probably not due to the relative deficiency of GSH-peroxidase activity in these cells.

\section{References and Notes}

1. Abei, H., ANd SUTER, H.: In: J. J. Yunis: Biochemical Methods in Red Cell Genetics, p. 255. (Academic Press, New York, 1969.

2. Baehner, R. L., Nathan, D. G., and Castle, W. B.: Oxidant injury of Caucasian glucose-6-phosphate dehydrogenase-deficient red blood cells by phagocytosing leukocytes during infection. J. Clin. Invest., 50: 2466 (1971).

3. Beutler, E.: Red Cell Metabolism: A Manual of Biochemical Methods, p. 103. (Grune and Stratton, New York, 1971).

4. Cohen, G., AND Hochstein, P.: Glucose-6-phosphate dehydrogenase and detoxification of hydrogen peroxide in human erythrocytes. Science, 134: 1756 (1961).

5. Cohen, G., And Hochstein, P.: Glutathione peroxidase: the primary agent for the elimination of hydrogen peroxide in erythrocytes. Biochemistry, 2: 1420 (1963).

6. Cohen, G., and Hochstein, P.: The generation of hydrogen peroxide in erythrocytes by hemolytic agents. Biochemistry, 7: 895 (1964).

7. DeChatelet, L. R., Cooper, M. R., and McCall, C.: Stimulation of the hexosemonophosphate shunt in human neutrophils by ascorbic acid: mechanism of action. Antimicrob. Agents Chemother. 1: 12 (1972).

8. Flohe, L., AND Brand, I.: Kinetics of glutathione peroxidase. Biochim. Biophys. Acta, 191: 541 (1969).

9. Gross, R. T., Bracci, R., Rudolph, N., Schroeder, E., and Kochen, J. A.: Hydrogen peroxide toxicity and detoxification in the erythrocytes of newborn infants. Blood, 29: 481 (1967).

10. JACOB, H. S., AND JANDL, J. S.: Effects of sulfhydryl inhibition on red blood cells. III. Glutathione in the regulation of the hexosemonophosphate pathway. J. Biol. Chem., 241: 4243 (1966).

11. Jones, P. E. H., And McCance, R. A.: Enzyme activities in the blood of infants and adults. Biochem. J., 43: 464 (1949).

12. Mills, G. C.: The purification and properties of glutathione peroxidase of erythrocytes. J. Biol. Chem., 234: 502 (1959).

13. Oski, F. A.: Red cell metabolism in the premature infant: II. The pentose phosphate pathway. Pediatrics, 39: 639 (1967).

14. Paglia, D. E., And Valentine, W. N.: Studies on the quantitative and qualitative characterization of erythrocyte glutathione peroxidase. J. Lab. Clin. Med., 70: 319 (1968).

15. Pankier, N. V., SRivastava, S. K., and Beutler, E.: Glutathione metabolism of the red cells: effect of glutathione reductase deficiency on the stimulation of hexosemonophosphate shunt under oxidative stress. Biochim. Biophys. Acta, 215: $456(1970)$.

16. Steinberg, M., ANd Nrcheles, T. F.: Erythrocyte glutathione peroxidase deficiency. Amer. J. Med., 50:542 (1971).

17. Fisher Scientific Co., Pittsburgh, $\mathrm{Pa}$.

18. Nutritional Biochemicals, Cleveland, Ohio.

19. Calbiochem, Los Angeles, Calif.

20. New England Nuclear, Boston, Mass.

21. We are indebted to Miss Linda Winn for her excellent technical assistance. We also thank Dr. David Nathan for useful comments during the preparation of this manuscript.

22. The present address of Dr. Bertil E. Glader is: Division of Hematology, Children's Hospital Medical Center, Boston, Mass.

23. Requests for reprints should be addressed to: Bertil E. GLader, M.D., Division of Hematology, Children's Hospital Medical Center, Boston, Mass. 02115 (USA).

24. Accepted for publication August 21, 1972. 